\title{
Different eclogite types from the Pakistan Himalaya and implications for exhumation processes
}

\author{
Franziska DH Wilke ${ }^{1 *}$, Patrick J O`Brien ${ }^{1}$ and M Ahmed Khan² \\ 1 Institut für Geowissenschaften, Universität Potsdam, D-14476 Potsdam, GERMANY \\ 2 University of Sargodha, Sargodha, PAKISTAN \\ * For correspondence, email:fwilke@geo.uni-potsdam.de
}

Metabasites were sampled from the Higher Himalayan Crystalline, south of the Main Mantle Thrust, from the Upper Kaghan Valley, Pakistan. These vary from corona dolerites outcropping around Saif ul Muluk in the south to coesite-eclogite close to the suture zone in the north. Peak pressures around $27 \mathrm{kbar}$, for a temperature of $690-750^{\circ} \mathrm{C}$, were obtained by $\mathrm{O}^{\prime}$ Brien et al. (2001) for coesitebearing (in omphacite) eclogites. The study of newly collected samples reveals coesite in both garnet and omphacite, which was confirmed by in situ raman spectroscopy. Both coesite-bearing and coesite-free eclogites show growth of amphiboles during exhumation. Within newly investigated coesite-bearing eclogites the presence of glaucophane cores within barroisite amphibole is noted. In addition, some eclogite bodies show leucocratic segregations containing phengite, albite, kyanite and/or zoisite consistent with decompression melting as described by Franz et al. (1995) for the Münchberg Massif, Germany: further examples are known from the Eastern Alps and Norwegian Western Gneiss Region. The important implications are not only that the continental crust of the Indian plate was subducted to depths of $\sim 100 \mathrm{~km}$ but that the exhumation path is complex and shows stages of cooling (glaucophane) followed by reheating (melting).

The glaucophane- and coesite-bearing eclogite was sampled in Saleh Gali, northwest of Gittidas, only a few hundred metres from the Indus Suture Zone. The very fresh eclogites exhibit a massive, fine grained $(<1 \mathrm{~mm})$ matrix with red garnet and dark green omphacite. Overgrowing this early fabric are larger $(>1$

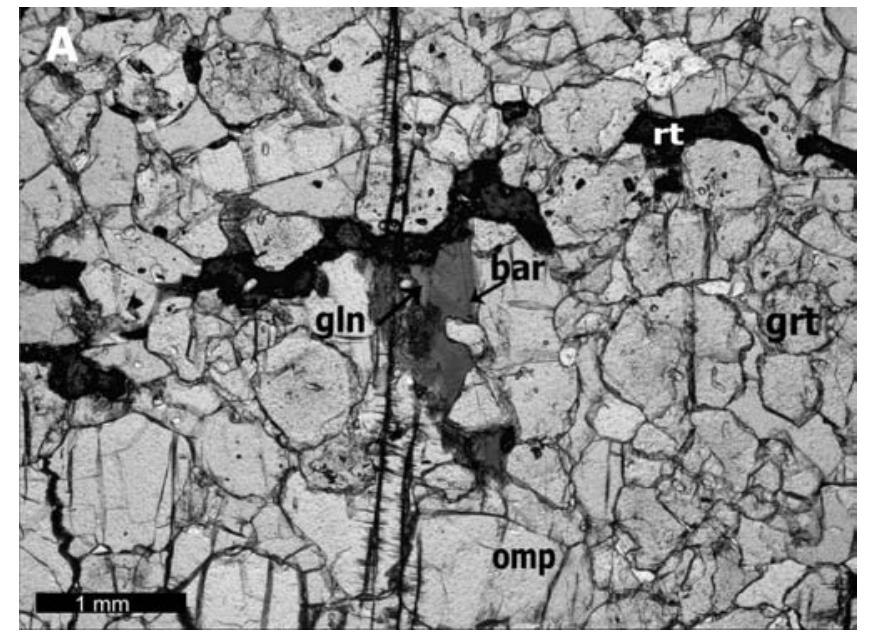

$\mathrm{mm}$ ) dark amphiboles. Microscopically anhedral, optical zoned garnets up to $0.8 \mathrm{~mm}$ sit within a weakly defined foliation formed by elongate omphacite, phengite and chains of rutile. Omphacite is up to $1 \mathrm{~mm}$ in length and mostly inclusion poor, whereas phengite is only $0.5 \mathrm{~mm}$ and rimmed by a thin biotite-bearing breakdown rim. Amphiboles with a conspicuous violet core and a dark green rim form small poikiloblasts enclosing the earlier phases. Coesite occurs as inclusions in omphacite and garnet, showing in both cases the typical radiating network of fractures. Coesite inclusions are best preserved in omphacite but only one example has been found in garnet so far. This might be due to a lack of garnet growth in the coesite field.

Optical zoning in garnet is only weakly reflected in mineral chemistry. Ca-poor cores $\mathrm{Alm}_{56} \operatorname{Prp}_{15} \mathrm{Sps}_{1} \mathrm{Grs}_{\mathrm{Adr}} \mathrm{Ad}_{27}$ are surrounded by $\mathrm{Alm}_{51} \operatorname{Prp}_{16} \mathrm{Sps}_{1} \mathrm{Grs}_{+} \mathrm{Adr}_{31}$ rims. The jadeite content of omphacite is in the range $\mathrm{X}_{\mathrm{Jd}} 0.36-0.39$ with $\mathrm{X}_{\mathrm{Aeg}} 0.08$ 0.14 . Violet amphibole cores are glaucophane (see also Lombardo et al. 2000) with a representative composition of $\mathrm{Na}_{0.27}\left(\mathrm{Na}_{1.59} \mathrm{C}\right.$ $\left.\mathrm{a}_{0.35} \mathrm{Fe}^{2+} 0.06\right) \quad\left(\mathrm{Mg}_{2.07} \mathrm{Fe}^{2+}{ }_{1.33} \mathrm{Fe}^{3+}{ }_{0.22} \mathrm{Al}_{1.38}\right)\left(\mathrm{Al}_{0.3} \mathrm{Si}_{7.7}\right) \mathrm{O}_{22}$ zoned to barroisite with $\mathrm{Na}_{0.37} \mathrm{~K}_{0.03}\left(\mathrm{Na}_{1.17} \mathrm{Ca}_{0.76} \mathrm{Fe}^{2+}{ }_{0.07}\right)\left(\mathrm{Mg}_{2.29} \mathrm{Fe}^{2+}{ }_{1.35} \mathrm{Fe}^{3+}{ }_{0.32}\right.$ $\left.\mathrm{Al}_{1.03}\right)\left(\mathrm{Al}_{0.59} \mathrm{Si}_{7.41}\right) \mathrm{O}_{22}$.

Leucocratic segregations containing phengite, albite, kyanite and/or zoisite are found in eclogites exposed Gittidas Nala. These generally strongly deformed and retrogressed rocks exhibit a very fine-grained, dark green to gray matrix with up to $2 \mathrm{~mm}$ black amphiboles overgrowing this fabric. Conspicuous are several

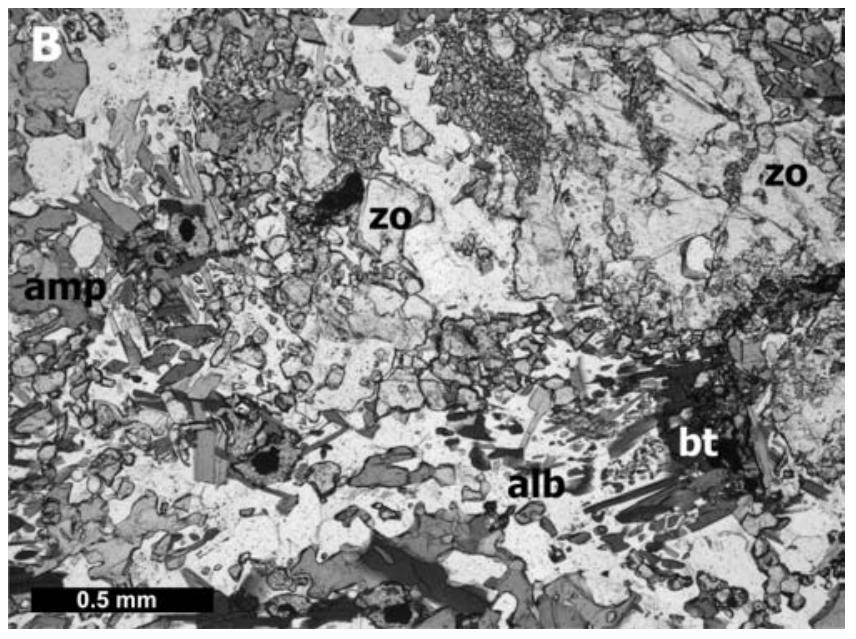

FIGURE 1. (A) Photomicrograph of a fresh eclogite containing glaucophane, rimmed by barroisite, omphacite and optically-zoned garnet disrupted by a chain of rutile. Scattering vertical cracks showing the last retrogression under greenschist facies conditions. (B) Leucocratic segregations containing zoisite, albite and biotite (after phengite). 
mm-sized clinozoisite crystals wrapped by the strongly developed foliation. In addition, the rock is cut by light-coloured veinlets containing phengite, albite, kyanite and locally also cm-sized rutile grains. In the microscope, anhedral, un-zoned garnets are mostly smaller than $0.25 \mathrm{~mm}$. There is no preferred orientation but garnet often forms bands especially around the margins of the large clinozoisites. Relicts of omphacite occur mainly as tiny inclusions in clinozoisite although locally primary coarse omphacite-bearing bands are still preserved. Amphibole exists in several generations: as inclusions in clinozoisite; as large, pale green porphyoblastic grains with partly irregular, retrograded outer rims; in symplectites after matrix omphacite and as euhedral nematoblastic amphibole of up to $0.1 \mathrm{~mm}$ in the melt zones. Phengite is rare and partially transformed to lepidoblastic biotite and albite symplectites. Zoisite is abundant, often up to $2.5 \mathrm{~mm}$ in longest dimension and mostly rich in inclusions, showing the complete range of an eclogite mineral assemblage. Kyanite is rare, mostly under $0.75 \mathrm{~mm}$ and only occurs in the leucocratic melt lenses.

Interestingly, eclogites containing coesite and/or glaucophane are also described from the Tso Morari area of Ladakh (de Sigoyer et al. 1997, Sachan et al. 2004). Their published P-T evolution is two-step with an isothermal decompression at $580 \pm 60^{\circ} \mathrm{C}$ from $20 \pm 3$ to $11 \pm 2 \mathrm{kbar}$ followed by an increase in temperature of $\sim 30^{\circ} \mathrm{C}$ which is reflected by the transformation of glaucophane to calcic amphibole. Based on our new observations we favour an S-shaped P-T path that starts from the coesite field, cools and decompresses into the glaucophane field $\left(15-20 \mathrm{kbar} / \sim 550^{\circ} \mathrm{C}\right)$ and later is reheated to $8-10 \mathrm{kbar} / 700^{\circ} \mathrm{C}$ within the amphibolite field, to cause melting. These conditions cover the finding of coesite, later grown glaucophane that gives way to a barroisite amphibole and the newly discovered melt segregations. Tectonically, this could reflect stacking of the crustal units at depth (i.e., cooling) followed by partial relaxation (heating) before final exhumation.

\section{References}

de Sigoyer J, S Guillot, J-M Lardeaux and G Mascle. 1997. Glaucophane bearing eclogites in the Tso Morari dome (eastern Ladakh, NW Himalaya). European Journal of Mineralogy 9: 1073-1083

Franz G and EA Smelik. 1995. Zoisite-clinozoisite bearing pegmatites and their importance for decompressional melting in eclogites. European Journal of Mineralogy 7: 1421-1436

Lombardo B, F Rolfo and R Compagnoni. 2000. Glaucophane and barroisite eclogites from the Upper Kaghan nappe: implications for the metamorphic history of the NW Himalaya. In: Khan MA, PJ Treloar, MP Searle, MQ Jan (eds), Tectonics of the Nanga Parbat Syntaxis and the Western Himalaya. Geological Society, London, Special Publications 170: 411-430.

O`Brien PJ, N Zotov, R Law, Khan M Ahmed and Jan M Qasim. 2001. Coesite in Himalayan eclogite and implications for models of IndiaAsia collision. Geology 29: 435-438

Sachan HK, BK Mukherjee, Y Ogasawara, S Maruyama, H Ishida, A Muko and N Yoshioka. 2004. Discovery of coesite from Indus Suture Zone (ISZ), Ladakh, India: Evidence for deep subduction. European Journal of Mineralogy 16: 235-240 